\title{
Non-Genetic and Genetic Effects on Growth Traits from Birth to 120 days of Age of $\mathbf{G}_{2}$ Sapera Goat
}

\author{
Anggraeni A, Saputra F, Hafid A, Ishak ABL \\ Indonesian Research Institute for Animal Production, PO Box 221, Ciawi, Bogor, Indonesia \\ E-mail: ria.anneke@yahoo.co.id
}

(received 21-04-2020; revised 05-05-2020; accepted 05-05-2020)

\begin{abstract}
ABSTRAK
Anggraeni A, Saputra F, Hafid A, Ishak ABL. 2020. Pengaruh non-genetik dan genetik sifat pertumbuhan pada saat lahir hingga umur 120 hari dari kambing $\mathrm{G}_{2}$ Sapera. JITV 25(2):48-59. DOI: http://dx.doi.org/10.14334/jitv.v25i2.2498

Informasi ragam genetik dan lingkungan diperlukan dalam program seleksi. Balai Penelitain Ternak (Balitnak) saat ini sedang melakukan seleksi awal pada sifat pertumbuhan dari kambing Sapera (50\% Saanen, 50\% PE). Studi ini bertujuan untuk mengetahui pengaruh non-genetik dan genetik terhadap sifat pertumbuhan sejak umur lahir - 120 hari dari anak-anak kambing $\mathrm{G}_{2}$ Sapera. Data bobot badan dan sejumlah ukuran tubuh diperoleh dari anak-anak umur lahir (105 ekor) sampai 120 hari (51 ekor). Data pertumbuhan setiap interval umur 30 hari dihitung secara interpolasi linier. Kontribusi dari pengaruh non-genetik dianalisa menerapkan Model Linier Umum untuk data tidak berimbang dengan pengaruh tetap mempertimbangkan jenis kelamin, tipe kelahiran, bulan- dan tahun lahir. Pengaruh genetik menerapkan model linier campuran mempertimbangkan pejantan sebagai variabel acak. Nilai heritabilitas dihitung dengan metode paternal halfsib. Faktor non-genetik sebagian besar tidak berpengaruh secara nyata $(\mathrm{P}>0,05)$ terhadap bobot badan dan ukuran tubuh pada kisaran umur pengamatan. Bobot umur 90 hari dan 120 hari dari anak jantan secara nyata lebih tinggi daripada anak betina $(\mathrm{P}<0,05)$. Tipe dan tahun lahir berpengaruh nyata $(\mathrm{P}<0.05)$ terhadap bobot badan dan beberapa ukuran tubuh pada umur tertentu. Namun bulan lahir tidak ada yang berpengaruh nyata $(\mathrm{P}>0,05)$ pada sifat pertumbuhan. Ragam genetik $\left(\mathrm{h}^{2}\right)$ dari bobot badan dan ukuran tubuh relatif rendah, yaitu $\mathrm{h}^{2}$ bobot badan $=0,11-0,19$ dan $\mathrm{h}^{2}$ ukuran tubuh $=0,03-0,24$. Pengecualian untuk bobot badan umur lahir dan 30 hari $\left(\mathrm{h}^{2}=0,59\right.$ dan 0.29), serta pada umur 30 hari dan 60 hari untuk lingkar panggul $\left(h^{2}=0,13-0,54\right)$. Sifat pertumbuhan anak kambing $\mathrm{G}_{2}$ Sapera dipengaruhi jenis kelamin dan tahun lahir tetapi tidak banyak dipengaruhi genetik pejantan.
\end{abstract}

Kata Kunci: Kambing Perah, Pertumbuhan, Genetik, Non Genetik

\section{ABSTRACT}

Anggraeni A, Saputra F, Hafid A, Ishak ABL. 2020. Non-genetic and genetic effects on the growth traits from birth to 120 days of age of $\mathrm{G}_{2}$ Sapera goat. JITV 25(2):48-59. DOI: http://dx.doi.org/10.14334/jitv.v25i2.2498

Information on non-genetic and genetic factors is required in the selection program. Indonesian Research Institute for Animal Production (IRIAP) has been conducting a selection of the growth traits of Sapera goat (50\% Saanen, 50\% PE). This research was aimed to study non-genetic and genetic effects on growth traits from birth to the age of 120 days old of the $2^{\text {nd }}$ generation $\left(\mathrm{G}_{2}\right)$ of Sapera goat. Data on body weight and measurement were collected from kids at birth (105 head.) to the age of 120 days old ( 51 head). The 30 days interval growth data were calculated by linear interpolation. Non-genetic effects were analyzed by General Linear Model for unbalanced data by considering sex, type of birth, the month of kidding, and year of kidding as fixed variables. The genetic component was analyzed by a mixed linear model by considering sire as a random variable. Heritability was estimated by the paternal half-sib method. Non-genetic factors mostly had no significant effect (P> $0.05)$ on body weight and measurement. The 90 days old and 120 days old males had higher weights than females $(\mathrm{P}<0.05)$. Birth type and year of kidding had significant effects $(\mathrm{P}<0.05)$ on body weight and some measurements at certain ages. No significant months of kidding effect on the growth traits $(\mathrm{P}>0.05)$. Heritability values of body weight $\left(\mathrm{h}^{2}=0.11-0.19\right)$ and body sizes $\left(h^{2}=0.03-0.24\right)$ were relatively low. Except high heritability values for birth weight and for body weight at 30 days old (h ${ }^{2}$ $=0.59$ and 0.29$)$, and for hip girth at 30 days old and at 60 days old $\left(h^{2}=0.13-0.54\right)$. The growth traits of $\mathrm{G}_{2}$ Sapera kids were affected by sex and year of kidding and slightly influenced by genetic (sires) factors.

Key Words: Dairy Goat, Growth, Genetic, Non-Genetic

\section{INTRODUCTION}

Dairy goat agribusinesses show a positive trend, so intensive dairy goat development has been growing especially in some locations in Java Island. To support this intensive dairy goat development, the availability of breeding stocks for possessing high genetic potency of milk production, and an adaptive tropical climate is required. This is, one of the other ways, attempted by crossing local female goats to male dairy goats from 
exotic breeds (Devendra 2012); Anggraeni \& Praharani 2017; Josiane et al. 2020). Crossbreeding of the local PE or Peranakan Etawah female to Saanen male was done by Indonesian Research Institute for Animal Production (IRIAP) for the expectation of resulting complementary effect of high milk production from the Saanen breed and a good tropical adaptation from PE breed (Anggraeni \& Praharani 2017; Anggraeni et al. 2020). Genetic improvement by crossing should be followed by selection activities to gather the superiority of both traits passed through to their offspring. Estimation of non-genetic and genetic factors related to growth trait is needed to develop a proper selection program and to achieve a good response of selection in dairy breeding program (Gholizadeh et al. 2010; CaroPetrovic et al. 2012; Kuthu et al. 2017; Josiane et al. 2020).

The potency of milk production of a dairy goat can be seen earlier from the growth traits of the kid such as body weight and body measurements (Waheed \& Khan 2011; Kuthu et al. 2017; Anggraeni et al. 2020). Phenotypes of growth are the expression of genetic, environment, and interaction of both (Kuthu et al. 2017; Selvam 2018; Josiane et al. 2020). Animals in high growth potency will be more tolerant in less suitable environmental conditions compared to the low growth ones (Přibyl et al. 2008). Some non-genetic factor had a significant effect on body weight at earlier ages such as sex, type of birth, seasons of birth, and year of birth (Bharathidhasan et al. 2009; Mabrouk et al. 2010; CaroPetrovic et al. 2012; Supakorn \& Pralomkarn 2012; Kaunang et al. 2013; Kugonza et al. 2014; Dudhe et al. 2015; Josiane et al. 2020; Mohammed et al. 2018). Male usually expressed higher body weight and body size than the female kid. Some studies reported the differences in birth weight and weaning weight of both sexes around 5.0-12.2\% and 6.0-20.0\% (Bharathidhasan et al. 2009; Mabrouk et al. 2010; Caro-Petrovic et al. 2012; Supakorn \& Pralomkarn 2012; Kugonza et al. 2014; Josiane et al. 2020). Whereas single birth kid usually expressed higher body weight and growth rate against twin and triplet kids (Bharathidhasan et al. 2009; Mabrouk et al. 2010, Supakorn \& Pralomkarn 2012; Dudhe et al. 2015; Josiane et al. 2020; Mohammed et al. 2018). Interaction between kidding season and year of kidding can also affect the body weights and growth rate of a young goat (Bharathidhasan et al. 2009; Supakorn \& Pralomkarn 2012; Caro-Petrovic et al. 2012; Dudhe et al. 2015; Selvam 2018; Mohammed et al. 2018).

Genetic variances are important to know the strengthening of a trait to be inherited to offspring. Estimation of genetic parameter becomes useful information to predict the effectiveness of the selection method and to obtain selection responses in achieving genetic improvement (Kuthu et al. 2017; Rout et al.
2018; Josiane et al. 2020). Heritability values as an indicator of additive genetic variability of birth weight and weaning weight at the earlier age of goat were reported quite varied from low to high. Estimated heritability resulted from some models of analyses from some goat breeds were reported for birth weight by $\mathrm{h}^{2}=$ 0.11-0.41 and weaning weight by $\mathrm{h}^{2}=0.110 .43$ (CaroPetrovic et al. 2012; Supakorn \& Pralomkarn 2012; Rout et al. 2018; Josiane et al. 2020). Body dimension that reflects the growth of body skeleton can be another indicator to do an initial selection on milk production in dairy goat (Waheed \& Khan 2011; Anggraeni et al. 2020). Heritability values of the morphometrics from various goat breeds were reported from low to high (Waheed \& Khan 2011; Josiane et al. 2020). Heritability values at $3 \mathrm{mo}$. interval age from birth to one year old of some goat breeds were reported from low to medium, successively chest girth by $\mathrm{h}^{2}=0.16$ (0.09-0.24), body length by $\mathrm{h}^{2}=0.05(0.0003-0.11)$, and wither height by $\mathrm{h}^{2}=0.13(0.07-0.21)$ (Josiane et al. 2020).

Information on non-genetic and genetic factors that affect the growth trait as an early indicator in selecting milk production of $\mathrm{G}_{2}$ Sapera goat was necessary. The purpose of this study was to examine the effect of nongenetic and genetic factors on the growth trait providing body weight and body measurement from birth to 120 days of age of $\mathrm{G}_{2}$ Sapera goat at IRIAP dairy goat station in Ciawi, Bogor, West Java.

\section{MATERIALS AND METHODS}

\section{Location}

This research was conducted at the dairy goat station of the Indonesian Research Institute for Animal Production (IRIAP), Ciawi Subdistrict, Bogor District, West Java. The IRIAP was located in an area of about 23 Ha in Banjar Waru Village, Ciawi Subdistrict, Bogor Regency, at the altitudes of 450 to $500 \mathrm{~m}$ asl with rainfall between 3,500 to $4,000 \mathrm{~mm}$ per year.

\section{Materials}

In this study, the $2^{\text {nd }}$ generation $\left(\mathrm{G}_{2}\right)$ Sapera goat (50\% Saanen, $50 \%$ PE) was used for a total number of 105 kids consisting of 47 males and 58 females during the year of birth of 2018 and 2019. The number of observed kids: at birth, 30 days, 60 days, 90 days (weaning age), and 120 days were successively 105 head, 105 head, 104 head, 104 head., and 51 head. These kids were the offsprings of the $G_{1}$ Sapera parents 


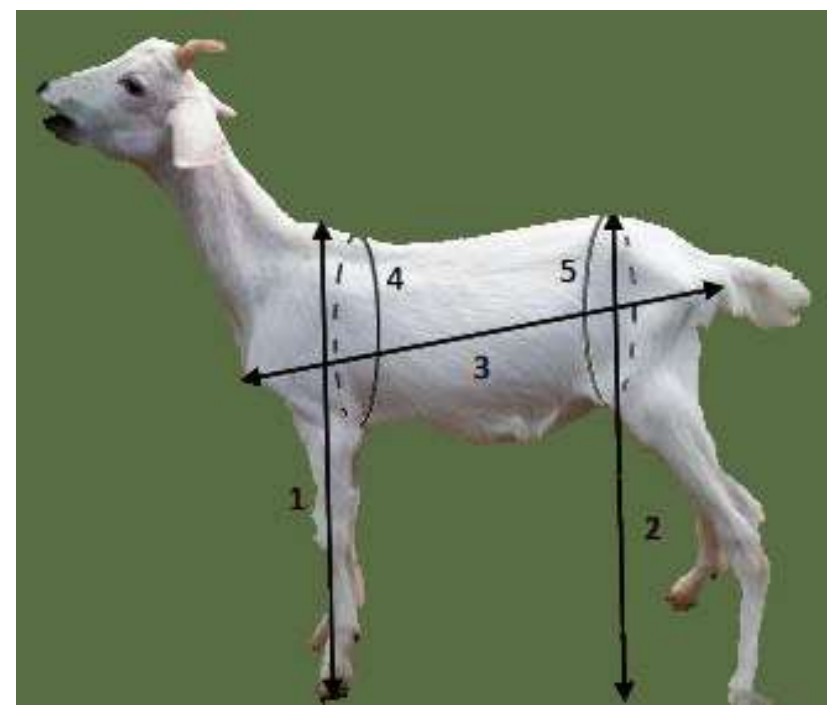

Figure 1. Body measurement of $2^{\text {nd }}$ generation Sapera Goat: $1=$ shoulder height $(\mathrm{SH}), 2=$ hip height $(\mathrm{HH}), 3=$ body length $(\mathrm{BL}), 4=$ chest girth (CG), 5= hip girth (HG)

(9 bucks, 46 does). The $\mathrm{G}_{1}$ Sapera females were previously synchronized by PGF $2 \alpha$ hormone. Mating was done naturally in the flocks with a ratio of a buck to does by 1:5-10. The birth occurred during February, March, and April in 2018 and 2019. However, birth in March was not too many.

\section{Management}

Kids after one day of birth were kept separately from the mothers in kid colony cages. Colostrum was given during the first four days after birth. Then milk was given by bottle twice a day. Kids at 2 weeks old were feed by legume of Calliandra, as well as a small number of concentrates. Weaning kids were feed by grasses ad-libitum and concentrate around $0.3 \mathrm{~kg}$ per day. Post-weaning goats were fed by grasses around $1.4 \mathrm{~kg}$ and concentrate for $0.4 \mathrm{~kg}$ per day. Male and female kids were kept in the same pen from birth until the weaning age, then female kids were kept separately to males about 6-10 heads per cage.

\section{Variables}

Data of body weight $(\mathrm{kg})$ were weighed using a sitting scale at an accuracy level of $0.1 \mathrm{~kg}$. Body measurements $(\mathrm{cm})$ were measured for shoulder height (SH), hip height $(\mathrm{HH})$, body length (BL), chest girth $(\mathrm{CG})$, and hip girth (HG). A measuring tape with a length of $150 \mathrm{~cm}$ at a sensitivity of $0.1 \mathrm{~cm}$ was used to measure chest girth and hip girth. A measuring stick with a length of $100 \mathrm{~cm}$ at a sensitivity of $0.1 \mathrm{~cm}$ was used to measure shoulder height, body length, and hip height.
The body weight and body sizes were recorded at the interval within 7-30 days. Excepting birth weight, individual records of both body weight and measurement were standardized to a 30 days interval by interpolation method to obtain body weight and body size at the ages of 30 days, 60 days, 90 days; and 120 days.

Non-genetic factors were observed for the following components and subcomponents: sex for male and female; type of birth for single, twin and triplets; months of kidding of February and March $\left(1^{\text {st }}\right)$ and for April $\left(2^{\text {nd }}\right)$; and year of kidding for 2018 and 2019.

\section{Statistical analysis}

\section{Non genetic component}

Effect of the non-genetic factor on each body weight and body measurement at each observed age of the $G_{2}$ Sapera kid were analyzed by ANOVA using Least Square Means for unbalanced data by PROC GLM of the SAS packets (SAS, 1999). The GLM statistical equation was as follow:

$$
\mathrm{Y}_{\mathrm{ijklmn}}=\mu+\mathrm{S}_{\mathrm{j}}+\mathrm{T}_{\mathrm{k}}+\mathrm{M}_{\mathrm{l}}+\mathrm{Y}_{\mathrm{m}}+\varepsilon_{\mathrm{ijklmn}}
$$

where,

$\mathrm{Y}_{\mathrm{ijklm}}$ : body weight or body measurement of $\mathrm{n}^{\text {th }}$ n kid, $j^{\text {th }}$ sex, $k^{\text {th }}$ birth type, $\mathrm{l}^{\text {th }}$ month of kidding, and $\mathrm{m}^{\text {th }}$ of year of kidding.

M : overall population mean

$S_{j} \quad: \quad$ effect of $j^{\text {th }}$ sex of the kid

$\mathrm{T}_{\mathrm{k}} \quad$ : effect of $\mathrm{k}^{\text {th }}$ type of birth

$\mathrm{M}_{1} \quad$ : effect of $1^{\text {th }}$ month of kidding

$\mathrm{Y}_{\mathrm{m}} \quad$ : effect of $\mathrm{m}^{\text {th }}$ year of kidding

$\varepsilon_{\mathrm{jklmn}}:$ residual error 
In the case of interaction between two factors resulted in no significant effect $(\mathrm{P}>0.05)$, then interaction was removed from the model to simplify the calculation process. Different LSMs between subclasses were tested by the Tukey test.

\section{Heritability}

Mixed Model was used to calculate sire variance as a random component, while fixed variables included sex, birth type, and year of birth. The statistical equation of the Linear Mixed Model was as follows:

$$
\mathrm{Y}_{\mathrm{ijklm}}=\mu+\mathrm{S}_{\mathrm{j}}+\mathrm{T}_{\mathrm{k}}+\mathrm{Y}_{\mathrm{l}}+\mathrm{S}_{\mathrm{m}}+\varepsilon_{\mathrm{ijklmn}}
$$

where,

$\mathrm{Y}_{\mathrm{ijklm}}$ : body weight or body measurement of $\mathrm{n}^{\text {th }}$

${ }_{n} \quad$ kid, $j^{\text {th }}$ sex, $\mathrm{k}^{\text {th }}$ birth type, $1^{\text {th }}$ year of kidding, and $\mathrm{m}^{\text {th }}$ sire

$\mu \quad$ : overall population mean

$S_{j} \quad: \quad$ fixed effect of $j^{\text {th }}$ sex of kid

$\mathrm{T}_{\mathrm{k}} \quad$ : fixed effect of $\mathrm{k}^{\text {th }}$ type of birth

$\mathrm{Y}_{1} \quad: \quad$ fixed effect of $1^{\text {th }}$ year of kidding

$\mathrm{s}_{\mathrm{m}} \quad:$ random effect of $\mathrm{m}^{\text {th }}$ sire

$\varepsilon_{\mathrm{jklmn}}:$ residual error

The assumed matrix model to estimate heritability value was as follows:

$$
\mathrm{Y}=\mathrm{XT} \pm \mathrm{Zu} \pm \mathrm{e}
$$

where,

$\mathrm{Y}$ : vector of observation $(\mathrm{n} \times 1)$

$\mathrm{T}$ : vector of fixed variables $(\mathrm{t} \times 1)$

$\mathrm{u}$ : vector of random variables (b x 1$)$

$\mathrm{X}$ : matrix related to fixed variables $(\mathrm{n} \times \mathrm{t})$

$\mathrm{Z}$ : vektor of error $(\mathrm{n} \times 1)$

e : vektor of error $(\mathrm{n} \times 1)$

Heritability values were computed by paternal halfsib analysis using VARCOMP procedures. Estimated heritability was obtained by the following equation (Mioč et al. 2011):

$$
h^{2}=\frac{4 \sigma^{2} s}{\sigma^{2} e+\sigma^{2} s}
$$

where:

$\mathrm{h}^{2}$ : heritability value

$\sigma^{2} \mathrm{~s}$ : component between sires

$\sigma^{2} \mathrm{e}$ : variance component of the kids within sire

\section{RESULTS AND DISCUSSION}

\section{Non-genetic effect}

Least square means (LSM) and standard error (SE) of the growth trait include body weight and body size from birth to 120 days of age of $\mathrm{G}_{2}$ Sapera kid classified by sex is in Table 1 , for the type of birth in
Table 2, for months of kidding in Table 3, and year of kidding in Table 4. The growth of animal can be reflected by the development of body weight in line with the age. Morphometrics is commonly measured based on body measurements of animals. Morphometrics reflects the development of body conformation and body skeleton. Several body measurements become important variables in the selection activity as an initial indicator of milk production due to the existence of a high positive genetic correlation between the two in dairy goat (Waheed \& Khan 2011).

\section{Sex}

The effect of sex on the body weight of $\mathrm{G}_{2}$ Sapera goat in Table 1 shows that the least-square means (LSMs) of the body weight of the male kid was not statistically different from the female kid across the ages $(\mathrm{P}>0.05)$. The exception was at weaning age where males were significantly heavier than females $(\mathrm{P}<0.05)$. LSMs of body weight of male and female at birth were $3.04 \pm 0.08 \mathrm{~kg}$ and $2.92 \pm 0.07 \mathrm{~kg}$ respectively, while at weaning age (90 days) were $9.88 \pm 0.37 \mathrm{~kg}$ and 8.98 $\pm 0.25 \mathrm{~kg}$ respectively. The different weaning weight by the sex was $0.90 \mathrm{~kg}$ or $10.02 \%$. However, by observing body weight at another age, it seemed different in body weight from birth to 120 days of the age between a male kid and a female kid by $2.40-7.72 \%$.

These results were still consistent with some previous studies. Male kid to female kid of Croatian goat had almost the same birth weight $(2.34 \mathrm{~kg}$ vs. 2.27 $\mathrm{kg})$, gaining a faster growth rate $(125.15 \mathrm{gr} / \mathrm{d}$. vs 106.96 gr/d.), thereby achieving a higher weaning weight (23.46 kg vs. $22.58 \mathrm{~kg}$ ) (Mioč et al. 2011). Bharathidhasan et al. (2009) reported body weight at the age from birth, 10 weeks, 20 weeks and 30 weeks of male to female were heavier successively by $10.0 \%(2.2$ $\mathrm{kg}$ vs. $2.0 \mathrm{~kg}), 6.0 \%(7.1 \mathrm{~kg}$ vs. $6.7 \mathrm{~kg}), 12.1 \%(11.1 \mathrm{~kg}$ vs. $9.9 \mathrm{~kg}$ ), and $20.3 \%$ (15.0 kg vs. $13.3 \mathrm{~kg})$. Heavier birth weight and weaning weight of male kid against female kid were reported from many goat breeds around 5.0-12.2\% and 6.0-20.0\% respectively (Bharathidhasan et al. 2009; Mabrouk et al. 2010; Caro-Petrovic et al. 2012; Supakorn \& Pralomkarn 2012; Kugonza et al. 2014; Dudhe et al. 2015; Josiane et al. 2020). The effect of sex on growth could be attributed to the different hormonal status between males and females.

Effect of sex on morphometrics of the $\mathrm{G}_{2}$ Sapera goat (Table 1) shows that both linear body size including shoulder height, hip height, and body length and non-linear body sizes providing chest girth and hip girth of the two sexes were not significantly different $(\mathrm{P}>0.05)$ for all ages. The exception was for $120-\mathrm{d}$ female kid had larger body length than the male kid $(\mathrm{P}>0.05)$. LSMs of body length of males and females at this age were $51.87 \pm 0.67 \mathrm{~cm}$ and $49.11 \pm 0.66 \mathrm{~cm}$, so the difference of both was $2.76 \mathrm{~cm}(5.62 \%)$. Observation of 
Anggareni et al. Non-genetic and genetic effects on growth traits from birth to 120 days of

Table 1. Least square means (LSM) and standard error (SE) of body weight and body measurements from birth to 120 days old by sex

\begin{tabular}{|c|c|c|c|c|c|c|c|c|c|c|c|}
\hline \multirow[t]{2}{*}{ Traits } & \multirow[t]{2}{*}{ Sex } & \multicolumn{2}{|c|}{ At Birth } & \multicolumn{2}{|c|}{30 days old } & \multicolumn{2}{|c|}{60 days old } & \multicolumn{2}{|c|}{90 days old } & \multicolumn{2}{|c|}{120 days old } \\
\hline & & $\mathrm{N}$ & $\mathrm{LSM} \pm \mathrm{SE}$ & $\mathrm{N}$ & $\mathrm{LSM} \pm \mathrm{SE}$ & $\mathrm{N}$ & $\mathrm{LSM} \pm \mathrm{SE}$ & $\mathrm{N}$ & $\mathrm{LSM} \pm \mathrm{SE}$ & $\mathrm{N}$ & $\mathrm{LSM} \pm \mathrm{SE}$ \\
\hline \multirow[t]{2}{*}{$\mathrm{BW}(\mathrm{kg})$} & Female & 58 & $2.92 \pm 0.07^{\mathrm{a}}$ & 58 & $4.78 \pm 0.12^{\mathrm{a}}$ & 58 & $6.94 \pm 0.17^{\mathrm{a}}$ & 58 & $8.98 \pm 0.25^{\mathrm{a}}$ & 30 & $10.04 \pm 0.35^{\circ}$ \\
\hline & Male & 47 & $3.04 \pm 0.08^{\mathrm{a}}$ & 47 & $5.13 \pm 0.14^{\mathrm{a}}$ & 46 & $7.21 \pm 0.23^{\mathrm{a}}$ & 46 & $9.88 \pm 0.37^{b}$ & 21 & $10.25 \pm 0.32^{2}$ \\
\hline \multirow[t]{2}{*}{$\mathrm{SH}(\mathrm{cm})$} & Female & 58 & $35.50 \pm 0.48^{\mathrm{a}}$ & 58 & $40.82 \pm 0.35^{\mathrm{a}}$ & 58 & $47.50 \pm 0.52^{\mathrm{a}}$ & 58 & $52.84 \pm 0.58^{\mathrm{a}}$ & 30 & $52.23 \pm 0.44^{2}$ \\
\hline & Male & 47 & $34.98 \pm 0.63^{\mathrm{a}}$ & 47 & $41.22 \pm 0.36^{\mathrm{a}}$ & 46 & $47.86 \pm 0.51^{\mathrm{a}}$ & 46 & $54.33 \pm 0.71^{\mathrm{a}}$ & 21 & $53.12 \pm 0.51^{\circ}$ \\
\hline \multirow[t]{2}{*}{$\mathrm{HH}(\mathrm{cm})$} & Female & 58 & $35.54 \pm 0.55^{\mathrm{a}}$ & 58 & $42.73 \pm 0.35^{\mathrm{a}}$ & 46 & $50.40 \pm 0.53^{\mathrm{a}}$ & 58 & $55.05 \pm 0.66^{\mathrm{a}}$ & 29 & $54.55 \pm 0.56^{2}$ \\
\hline & Male & 47 & $36.01 \pm 0.64^{\mathrm{a}}$ & 47 & $42.98 \pm 0.34^{\mathrm{a}}$ & 58 & $50.49 \pm 0.57^{\mathrm{a}}$ & 46 & $56.00 \pm 0.80^{\mathrm{a}}$ & 21 & $55.59 \pm 0.60^{2}$ \\
\hline \multirow[t]{2}{*}{$\mathrm{BL}(\mathrm{cm})$} & Female & 58 & $29.54 \pm 0.67^{\mathrm{a}}$ & 58 & $37.90 \pm 0.33^{\mathrm{a}}$ & 58 & $44.55 \pm 0.59^{\mathrm{a}}$ & 58 & $52.36 \pm 0.90^{\mathrm{a}}$ & 30 & $49.11 \pm 0.66^{2}$ \\
\hline & Male & 47 & $30.21 \pm 0.66^{\mathrm{a}}$ & 47 & $38.28 \pm 0.38^{\mathrm{a}}$ & 46 & $44.87 \pm 0.72^{\mathrm{a}}$ & 46 & $52.67 \pm 1.00^{\mathrm{a}}$ & 21 & $51.87 \pm 0.67^{\mathrm{b}}$ \\
\hline \multirow[t]{2}{*}{$\mathrm{CG}(\mathrm{cm})$} & Female & 58 & $31.60 \pm 0.58 \mathrm{a}$ & 58 & $39.00 \pm 0.33^{\mathrm{a}}$ & 58 & $46.41 \pm 0.48^{\mathrm{a}}$ & 58 & $49.89 \pm 1.12^{\mathrm{a}}$ & 30 & $50.17 \pm 0.49^{2}$ \\
\hline & Male & 47 & $31.52 \pm 0.64^{\mathrm{a}}$ & 47 & $39.14 \pm 0.34^{\mathrm{a}}$ & 46 & $46.68 \pm 0.45^{\mathrm{a}}$ & 46 & $51.30 \pm 0.75^{\mathrm{a}}$ & 21 & $51.90 \pm 0.44^{\circ}$ \\
\hline \multirow[t]{2}{*}{$\mathrm{HG}(\mathrm{cm})$} & Female & 58 & $24.67 \pm 0.99^{\mathrm{a}}$ & 58 & $35.77 \pm 0.30^{\mathrm{a}}$ & 58 & $44.66 \pm 0.78^{\mathrm{a}}$ & 58 & $48.46 \pm 0.78^{\mathrm{a}}$ & 30 & $54.87 \pm 0.85^{\circ}$ \\
\hline & Male & 47 & $24.67 \pm 1.37^{\mathrm{a}}$ & 47 & $35.99 \pm 0.40^{\mathrm{a}}$ & 46 & $44.71 \pm 0.93^{\mathrm{a}}$ & 46 & $50.03 \pm 1.05^{\mathrm{a}}$ & 21 & $56.27 \pm 1.00^{\circ}$ \\
\hline
\end{tabular}

BW: body weight, SH: shoulder height, HH: hip height, BL: body length, CG: chest girth, HG: hip girth
Different letters between row for a and b were statistically significant difference $(\mathrm{P}<0.05)$ and for a and $\mathrm{c}$ were very significant difference $(\mathrm{P}<0.01)$ 
the body measurement by the respective age presented by male body sizes was slightly larger than females. Even at the birth male kid to female kid had shorter shoulder height and chest girth, while the hip circumference of both was similar. The high difference in body size of male kid to a female kid from birth to 120 days of age were found for hip height by $0.09-1.04$ $\mathrm{cm}(0.6-1.9 \%)$ and body length by $0.31-2.76 \mathrm{~cm}(0.7-$ $5.6 \%$ ). While the difference between the two at the age of $30 \mathrm{~d}$. to $120 \mathrm{~d}$. kid was: for shoulder height by 0.40 $1.49 \mathrm{~cm}(0.01-2.97 \%)$, chest girth by $0.14-1.54 \mathrm{~cm}$ $(0.36-3.32 \%$, and hip girth by $0.05-1.57 \mathrm{~cm}(0.11$ $0.61 \%)$. The difference in body size, when compared to those in body weight, at the respective age, due to sex differences was relatively low. This result indicated that the growth of the body skeleton was slower than those of the body weight of the kid.

Body measurement at the birth of the $\mathrm{G}_{2}$ Sapera goats in this study was quite larger than those of the local Sirohi goat in India as reported from the study by Dudhe et al. (2015). Body length, wither height, and body girth of these kids at birth was $28.3 \mathrm{~cm}, 31.0 \mathrm{~cm}, 31.2 \mathrm{~cm}$ respectively. For the development of a selection index method based on body weight and body dimension to improve milk production in Dhofari goat breed in Turkey, varying phenotypes were found for body length, body height, heart girth, and rear girth at birth, successively $31.4 \mathrm{~cm}(27.0-37.0 \mathrm{~cm}), 34.7 \mathrm{~cm}(30.0-$ $41.0 \mathrm{~cm}), 33.6 \mathrm{~cm}(25.0-42.0 \mathrm{~cm})$, and $37.0 \mathrm{~cm}(27.0$ $47.0 \mathrm{~cm}$ ). The sex reported by Jafari and Hashemi (2014) affects the number of body measurements from local Makuie sheep in Iran. Male had greater body dimension to female as indicated by differences in wither height, rump height, and body length successively by $4 \mathrm{~cm}(12.9 \%), 3.8 \mathrm{~cm}(4.8 \%), 1.1 \mathrm{~cm}$ $(2.2 \%), 2.6 \mathrm{~cm}(4.1 \%)$ and $1.0 \mathrm{~cm}(3.3 \%)$. Dudhe et al. (2015) in Sirohi goat in India also found the influence of sex on body size as shown by the larger body dimension of male kid over a female at the age of birth, 3 months (weaning), 6 months 9 months and one yearold successively for body weight by $2.51 \%, 3.80 \%$, $3.05 \%, 3.02 \%$, and $2.87 \%$, body length by $2.36 \%$, $3.41 \%, 2.86 \%, 6.81 \%$ and $3.24 \%$; and chest girth by $2.53 \%, 3.67 \%, 3.03 \%, 2.98 \%$ and $2.85 \%$. The significant influence of sex factor on the growth trait may be due to physiological characteristics and endocrinal system, type, and measure of hormone secretion, especially sexual hormones.

\section{Type of birth}

The effect of birth type on growth trait of both body weight and body size from birth to $120 \mathrm{~d}$. age of the $\mathrm{G}_{2}$ Sapera goat is presented in Table 2. A significant difference by birth type on body weight only evidenced at the birth $(\mathrm{P}<0.01)$ instead of the other age. Single, twin and triplets kid had birth weight by $3.37 \pm 0.12 \mathrm{~kg}$, $3.01 \pm 0.06 \mathrm{~kg}$, and $2.56 \pm 0.12 \mathrm{~kg}$ respectively, so that the weight benefit of the single kid to twin is $0.36 \mathrm{~kg}$ $(11.96 \%)$ and to triplets is $0.81 \mathrm{~kg}(31.64 \%)$. Factors that cause smaller birth weight in multiple births might be due to the capacity of the mother uterus when pregnant to accommodate more fetuses than a single fetus. The capacity of the uterus in twin pregnancy will cause fetal competition in getting nutrients from the mother, thus causing low birth weight.

Results show that birth type affected body weight inconsistently after birth, even twin body weights could be greater against single birth weight, although the differences were not significant. These results differed from some previous studies that reported a significant effect of birth type on the body weight from various goat breeds (Bharathidhasan et al. 2009; Mabrouk et al. 2010; Supakorn \& Pralomkarn 2012; Josiane et al. 2020). Birth weight, weaning weight and daily growth rate of both ages in Barbari goat from the single kid was successively $1.94 \pm 0.08 \mathrm{~kg}, \quad 7.16 \pm 0.44 \mathrm{~kg}$, and $55.56 \pm 4.80 \mathrm{gr} / \mathrm{d}$. being higher than twins that were successively $1.83 \pm 0.06 \mathrm{~kg}, \quad 6.71 \pm 0.40 \mathrm{~kg}, \quad$ and $55.45 \pm 4.41 \mathrm{gr} / \mathrm{d}$ respectively (Bharathidhasan et al. 2009). Mabrouk et al. (2010) found significant differences in body weight of the single kid over the twin at each one-month interval of the age, from birth to five months old, sequentially $7.66 \%, 13.48 \%, 21.38 \%$, $19.74 \%, 27.44 \%$, and $17.67 \%$. Several studies also reported that single kid had benefits against the twin for birth weight by $6.01-37.62 \%$ and weaning weight by 3.58-25.37 \%; while those from single kid against triplets for birth weight by $25.37-37.62 \%$ and weaning weight by $25.37-31.35 \%$ (Bharathidhasan et al. 2009; Supakorn \& Pralomkarn 2012; Mioč et al. 2011; Dudhe et al. 2015; Mohammed et al. 2018).

The individual body measurement observed in the Sapera $\mathrm{G}_{2}$ kid increased by age (Table 2). However, a significant effect $(\mathrm{P}<0.05)$ of birth type was only found on shoulder height at birth and 30 days of age, as well as chest circumference at 120 days of age. Whilst there was no significant effect of birth type on body size $(\mathrm{P}>0.05)$. At birth and weaning age, a shoulder height of the single kid $(36.74 \pm 1.18 \mathrm{~cm}, 43.64 \pm 0.83 \mathrm{~cm})$ and twin $(36.10 \pm 0.46 \mathrm{~cm}, 43.07 \pm 0.29)$ was significantly higher than triplets $(34.49 \pm 1.02 \mathrm{~cm}, 41.85 \pm 0.49 \mathrm{~cm})$. The difference between single kid to twin was by 0.64 $\mathrm{cm}(1.77 \%)$ and to triplet by $2.25 \mathrm{~cm}(6.52 \%)$, while at the 30 days old the difference was respectively by 0.57 $\mathrm{cm}(1.32 \%)$ and $1.79 \mathrm{~cm}(4.28 \%)$. At the 120 days old, chest girth of the single kid $(53.06 \pm 0.8 \mathrm{~cm})$ differed from the twin $(50.48 \pm 0.36 \mathrm{~cm})$ and the triplets $(49.56 \pm 0.89 \mathrm{~cm})$. The superiority of the chest girth of the single kid to twin was $2.58 \mathrm{~cm}(5.11 \%)$ and to triplets by $3.5 \mathrm{~cm}(7.06 \%)$. 
Table 2. Least square means (LSM) and standard error (SE) of body weight and body measurements from birth to 120 days old by type of birth

\begin{tabular}{|c|c|c|c|c|c|c|c|c|c|c|c|}
\hline \multirow[t]{2}{*}{ Traits } & \multirow[t]{2}{*}{ Type of Birth } & \multicolumn{2}{|c|}{ At Birth } & \multicolumn{2}{|c|}{30 days old } & \multicolumn{2}{|c|}{60 days old } & \multicolumn{2}{|c|}{90 days old } & \multicolumn{2}{|c|}{120 days old } \\
\hline & & $\mathrm{N}$ & $\mathrm{LSM} \pm \mathrm{SE}$ & $\mathrm{N}$ & $\mathrm{LSM} \pm \mathrm{SE}$ & $\mathrm{N}$ & $\mathrm{LSM} \pm \mathrm{SE}$ & $\mathrm{N}$ & $\mathrm{LSM} \pm \mathrm{SE}$ & $\mathrm{N}$ & $\mathrm{LSM} \pm \mathrm{SE}$ \\
\hline \multirow[t]{3}{*}{$\mathrm{BW}(\mathrm{kg})$} & 1 & 13 & $3.37 \pm 0.12^{\mathrm{a}}$ & 13 & $4.88 \pm 0.25^{\mathrm{a}}$ & 13 & $7.28 \pm 0.17^{\mathrm{a}}$ & 13 & $9.27 \pm 1.69^{\mathrm{a}}$ & 9 & $10.75 \pm 0.74^{\mathrm{a}}$ \\
\hline & 2 & 66 & $3.01 \pm 0.06^{\mathrm{b}}$ & 66 & $4.96 \pm 0.11^{\mathrm{a}}$ & 65 & $6.96 \pm 0.46^{\mathrm{a}}$ & 65 & $9.54 \pm 0.49^{\mathrm{a}}$ & 31 & $10.11 \pm 0.31^{\mathrm{a}}$ \\
\hline & 3 & 26 & $2.56 \pm 0.12^{\mathrm{c}}$ & 26 & $4.90 \pm 0.20^{\mathrm{a}}$ & 26 & $6.98 \pm 0.27^{\mathrm{a}}$ & 26 & $9.49 \pm 0.46^{\mathrm{a}}$ & 11 & $9.58 \pm 0.40^{\mathrm{a}}$ \\
\hline \multirow[t]{3}{*}{$\mathrm{SH}(\mathrm{cm})$} & 1 & 13 & $36.74 \pm 1.18^{\mathrm{a}}$ & 13 & $43.64 \pm 0.83^{\mathrm{b}}$ & 13 & $50.73 \pm 1.12^{\mathrm{a}}$ & 13 & $53.90 \pm 4.08^{\mathrm{a}}$ & 9 & $55.50 \pm 1.11^{\mathrm{a}}$ \\
\hline & 2 & 66 & $36.10 \pm 0.46^{\mathrm{a}}$ & 66 & $43.07 \pm 0.29^{b}$ & 65 & $50.37 \pm 0.48^{\mathrm{a}}$ & 65 & $53.50 \pm 4.08^{\mathrm{a}}$ & 31 & $55.24 \pm 0.54^{\mathrm{a}}$ \\
\hline & 3 & 26 & $34.49 \pm 1.02^{\mathrm{b}}$ & 26 & $41.85 \pm 0.49^{\mathrm{a}}$ & 26 & $49.64 \pm 0.84^{\mathrm{a}}$ & 26 & $52.18 \pm 1.73^{\mathrm{a}}$ & 10 & $54.49 \pm 0.77^{\mathrm{a}}$ \\
\hline \multirow[t]{3}{*}{$\mathrm{HH}(\mathrm{cm})$} & 1 & 13 & $36.10 \pm 1.18^{\mathrm{a}}$ & 13 & $43.07 \pm 0.83^{\mathrm{b}}$ & 13 & $50.37 \pm 1.12^{\mathrm{a}}$ & 13 & $56.90 \pm 4.08^{\mathrm{a}}$ & 9 & $55.50 \pm 1.11^{\mathrm{a}}$ \\
\hline & 2 & 66 & $36.74 \pm 0.46^{\mathrm{a}}$ & 66 & $43.64 \pm 0.29^{\mathrm{b}}$ & 65 & $50.73 \pm 0.48^{\mathrm{a}}$ & 65 & $55.50 \pm 4.08^{\mathrm{a}}$ & 31 & $55.24 \pm 0.54^{\mathrm{a}}$ \\
\hline & 3 & 26 & $34.49 \pm 1.02^{\mathrm{b}}$ & 26 & $41.85 \pm 0.49^{\mathrm{a}}$ & 26 & $49.64 \pm 0.84^{\mathrm{a}}$ & 26 & $54.18 \pm 1.73^{\mathrm{a}}$ & 10 & $54.49 \pm 0.77^{\mathrm{a}}$ \\
\hline \multirow[t]{3}{*}{$\mathrm{BL}(\mathrm{cm})$} & 1 & 13 & $29.00 \pm 1.45^{\mathrm{a}}$ & 13 & $38.23 \pm 0.98^{a}$ & 13 & $44.35 \pm 1.26^{\mathrm{a}}$ & 13 & $50.37 \pm 3.81^{\mathrm{a}}$ & 9 & $51.75 \pm 1.42^{\mathrm{a}}$ \\
\hline & 2 & 66 & $30.47 \pm 0.52^{\mathrm{a}}$ & 66 & $38.24 \pm 0.27^{\mathrm{a}}$ & 65 & $45.41 \pm 0.61^{\mathrm{a}}$ & 65 & $53.08 \pm 1.26^{\mathrm{a}}$ & 31 & $50.56 \pm 0.65^{\mathrm{a}}$ \\
\hline & 3 & 26 & $30.16 \pm 0.90^{\mathrm{a}}$ & 26 & $37.80 \pm 0.59^{\mathrm{a}}$ & 26 & $44.37 \pm 0.81^{\mathrm{a}}$ & 26 & $52.09 \pm 1.66^{\mathrm{a}}$ & 11 & $49.16 \pm 0.91^{\mathrm{a}}$ \\
\hline \multirow[t]{3}{*}{$\mathrm{CG}(\mathrm{cm})$} & 1 & 13 & $31.29 \pm 1.45^{\mathrm{a}}$ & 13 & $39.22 \pm 0.64^{\mathrm{a}}$ & 13 & $47.13 \pm 1.10^{\mathrm{a}}$ & 13 & $50.45 \pm 2.43^{\mathrm{a}}$ & 9 & $53.06 \pm 0.84^{\mathrm{b}}$ \\
\hline & 2 & 66 & $31.76 \pm 0.52^{\mathrm{a}}$ & 66 & $39.13 \pm 0.28^{\mathrm{a}}$ & 65 & $46.50 \pm 0.39^{\mathrm{a}}$ & 65 & $50.53 \pm 0.96^{\mathrm{a}}$ & 31 & $50.48 \pm 0.36^{\mathrm{a}}$ \\
\hline & 3 & 26 & $31.63 \pm 0.90^{\mathrm{a}}$ & 26 & $38.82 \pm 0.56^{\mathrm{a}}$ & 26 & $46.00 \pm 0.73^{\mathrm{a}}$ & 26 & $50.80 \pm 1.27^{\mathrm{a}}$ & 11 & $49.56 \pm 0.89^{a}$ \\
\hline \multirow[t]{3}{*}{$\mathrm{HG}(\mathrm{cm})$} & 1 & 13 & $23.92 \pm 2.58^{\mathrm{a}}$ & 13 & $35.54 \pm 0.64^{\mathrm{a}}$ & 13 & $42.97 \pm 1.92^{\mathrm{a}}$ & 13 & $47.60 \pm 2.05^{\mathrm{a}}$ & 9 & $52.26 \pm 1.29^{\mathrm{a}}$ \\
\hline & 2 & 66 & $24.17 \pm 1.04^{\mathrm{a}}$ & 66 & $36.14 \pm 0.30^{\mathrm{a}}$ & 65 & $46.50 \pm 0.78^{\mathrm{a}}$ & 65 & $50.14 \pm 1.29^{\mathrm{a}}$ & 31 & $5258 \pm 0.85^{\mathrm{a}}$ \\
\hline & 3 & 26 & $25.93 \pm 1.47^{\mathrm{a}}$ & 26 & $35.96 \pm 0.55^{\mathrm{a}}$ & 26 & $44.58 \pm 0.97^{\mathrm{a}}$ & 26 & $49.99 \pm 2.32^{\mathrm{a}}$ & 11 & $51.88 \pm 1.52^{\mathrm{a}}$ \\
\hline
\end{tabular}

BW: body weight, SH: shoulder height, HH: hip height, BL: body length, CG: chest girth, HG: hip girth

Different letters between row for $\mathrm{a}$ and $\mathrm{b}$ were statistically significant difference $(\mathrm{P}<0.05)$ and for a and $\mathrm{c}$ were very significant difference $(\mathrm{P}<0.01)$ 
Body measurement of single kid were higher than multiple kid were obtained by a number of previous studies (Jafari \& Hashemi 2014; Dudhe et al. 2015; Sarma et al. 2019). Dudhe et al. (2015) studied in native Sirohi goat in India at birth, 3 months, 6 months, 9 months and 12 months old, found larger body size of single kid to twin for body height successively by 2.19 $\mathrm{cm}(7.32 \%), 2.11 \mathrm{~cm}$ (4.18\%), $2.10 \mathrm{~cm}$ (3.71\%), 1.40 $\mathrm{cm}(2.29 \%)$, and $1.34 \mathrm{~cm}(2.02 \%)$; body lengths by 2.21 $\mathrm{cm}(8.12 \%), 1.87 \mathrm{~cm}(3.98 \%), 2.20 \mathrm{~cm}$ (4.16\%), 1.42 $\mathrm{cm}(2.51 \%), 1.11 \mathrm{~cm}(1.79 \%)$; and body girth by 2.16 $\mathrm{cm}$ (7.17\%), $2.17 \mathrm{~cm}$ (4.29\%), $2.06 \mathrm{~cm}$ (3.58\%), 1.25 $\mathrm{cm}(2.03 \%)$ and $1.48 \mathrm{~cm}(2.22 \%)$.

\section{Month and year of kidding}

Months of kidding of the $\mathrm{G}_{2}$ Sapera kid in this study were classified based on two months of kidding, namely the first for February and March in 2018 and the second for April in 2019. Table 3 shows that month of kidding gave no significant effect on body weight and body size at all ages $(\mathrm{P}>0.05)$. This shows that the growth trait did not vary within the two months of kidding observed. This was reasonable as the two months of kidding were still in one kidding season (end of the rainy season). This result differed from those obtained by Mabrouk et al. (2010) for goat in the arid region of Tunisia where the month of birth (January-March and December) affected body weight and body size at birth to age 5 months old. These results were still in line with the study of Sarma et al. (2019) that found a significant effect of the seasons on early growth trait of mountain goat in India. Differences in body weight and body measurement associated with differences in the birth season of goat and also sheep were reported from some studies (Bharathidhasan et al. 2009; Supakorn \& Pralomkarn 2012; Caro-Petrovic et al. 2012; Dudhe et al. 2015; Selvam 2018; Mohammed et al. 2018).

Table 4 shows that years of kidding (2018 and 2019) did not have a significant effect on body weight and all body measurements from birth until the weaning age. Significant year of kidding effects on body weight and body size were found at 120 days old kid $(\mathrm{P}<0.05)$ rather than shoulder height and chest girth $(\mathrm{P}>0.05)$. It seemed body weight and body measurements slightly decreased in the latter year of kidding might be due to the older age does. Most of these does get older (5-8 yr. old) at year of kidding 2019 than 2018. This is in line with the findings from some studies stating that body weight and body size of goat decreased after the does reaching the peak phase of production (Mabrouk et al. 2010; Anggraeni 2014).

However different results were reported by Dudhe et al. (2015) in Sirohi goat in India that found a significant influence year of kidding on body weight, body height, body length, and girth size at the successive three-month interval from birth to 12 months old. The significant influence of birth year either on body weight or body size was also obtained by some previous studies (Supakorn \& Pralomkarn 2012; CaroPetrovic et al. 2012; Jafari \& Hashemi 2014; Dudhe et al. 2015; Selvam 2018). Differences due to year of kidding might be caused by differences in management, food availability (quantity and quality), disease, and climate condition (rainfall, relative humidity, and temperature) (Jafari \& Hashemi 2014; Dudhe et al. 2015).

\section{Genetic effect}

Heritability is part of phenotype variances that resulted from differences in heredity among the genes and gene combination of individual genotype. Prediction of response to selection and efficiency of a breeding program to result in genetic progress rely on the information on the heritability of the trait under consideration. Estimated $\mathrm{G}_{2}$ Sapera goat heritability from birth to 120 days of age are presented in Table 5 . Heritability value of body weight of the kid at birth was high $\left(\mathrm{h}^{2}=0.59\right)$, and at $30 \mathrm{~d}$. age $\left(\mathrm{h}^{2}=0.29\right)$ was moderate. Whereas heritability value at the age of 60 days old $\left(\mathrm{h}^{2}=0.11\right), 90$ days old $\left(\mathrm{h}^{2}=0.16\right)$, and 120 days old $\left(h^{2}=0.15\right)$ were low. Likewise, heritability value of body measurement in all ages were low providing shoulder height $\left(\mathrm{h}^{2}=0.10-0.18\right)$, hip height $\left(h^{2}=0.04-0.08\right)$, body length $\left(h^{2}=0.03-0.09\right)$, and chest girth $\left(h^{2}=0.09-0.15\right)$. Heritability by moderate value however was obtained for chest girth at $30 \mathrm{~d}$. age $\left(\mathrm{h}^{2}=\right.$ $0.24)$, and moderate to high value for hip girth $\left(\mathrm{h}^{2}=\right.$ 0.23-0.34). Classification of the heritability was by referring to Mioč et al. (2011) stated highly heritable trait for $\mathrm{h}^{2}$ value exceeded 0.40 , whilst lowly heritable traits for $\mathrm{h}^{2}$ value below 0.15 .

Heritability value of $\mathrm{G}_{2}$ Sapera kid growth trait in this study was calculated from the sire variance component. So that the variance of body weight and body measurement likely due to the variations between sires. Dudhe et al. (2015) reported a high heritability value of body measurement that was estimated by the sire component. Results of some studies explained that sire significantly influenced morphometric trait showing the presence of additive genetic variability among these traits and the significant effect of sire might be related to the appearance of the family of the buck used.

A previous study by Dudhe et al. (2015) obtained a relatively high value of the heritability of growth trait in Sirohi goat. Heritability estimated in Dhorfari goat in Egypt for body weight, body length, body height, hip girth, and rear girth were successively $0.41,0.33,0.82$, 0.90. While Waheed \& Khan (2011) reported genetic additive variation within a wide range for goat growth 
Anggareni et al. Non-genetic and genetic effects on growth traits from birth to 120 days of

Table 3. Least square means (LSM) and standard error (SE) of body weight and body measurements from birth to 90 days old by month of kidding.

\begin{tabular}{|c|c|c|c|c|c|c|c|c|c|}
\hline \multirow[t]{2}{*}{ Traits } & \multirow[t]{2}{*}{ Month of Kidding } & \multicolumn{2}{|c|}{ At Birth } & \multicolumn{2}{|c|}{30 days old } & \multicolumn{2}{|c|}{60 days old } & \multicolumn{2}{|c|}{90 days old } \\
\hline & & $\mathrm{N}$ & $\mathrm{LSM} \pm \mathrm{SE}$ & $\mathrm{N}$ & $\mathrm{LSM} \pm \mathrm{SE}$ & $\mathrm{N}$ & $\mathrm{LSM} \pm \mathrm{SE}$ & $\mathrm{N}$ & $\mathrm{LSM} \pm \mathrm{SE}$ \\
\hline \multirow[t]{2}{*}{ BW (kg) } & Feb-March & 53 & $2.84 \pm 0.08^{\mathrm{a}}$ & 53 & $4.38 \pm 0.09^{\mathrm{a}}$ & 53 & $7.62 \pm 0.16^{\mathrm{a}}$ & 53 & $10.52 \pm 0.24^{\mathrm{a}}$ \\
\hline & April & 52 & $3.12 \pm 0.06^{\mathrm{a}}$ & 52 & $5.50 \pm 0.11^{\mathrm{a}}$ & 51 & $6.53 \pm 0.20^{\mathrm{a}}$ & 51 & $8.35 \pm 0.37^{\mathrm{a}}$ \\
\hline \multirow[t]{2}{*}{$\mathrm{SH}(\mathrm{cm})$} & Feb-March & 53 & $35.08 \pm 0.52^{\mathrm{a}}$ & 53 & $41.57 \pm 0.33^{\mathrm{a}}$ & 53 & $48.13 \pm 0.50^{\mathrm{a}}$ & 53 & $54.53 \pm 0.39^{\mathrm{a}}$ \\
\hline & April & 52 & $35.40 \pm 0.55^{\mathrm{a}}$ & 52 & $40.46 \pm 0.38^{\mathrm{a}}$ & 51 & $47.24 \pm 0.54^{\mathrm{a}}$ & 51 & $52.64 \pm 0.82^{\mathrm{a}}$ \\
\hline \multirow[t]{2}{*}{$\mathrm{HH}(\mathrm{cm})$} & Feb-March & 52 & $33.03 \pm 0.50^{\mathrm{a}}$ & 53 & $44.85 \pm 0.34^{\mathrm{b}}$ & 53 & $51.37 \pm 0.54^{\mathrm{a}}$ & 53 & $56.37 \pm 0.38^{\mathrm{a}}$ \\
\hline & April & 53 & $38.52 \pm 0.67^{\mathrm{a}}$ & 52 & $40.85 \pm 0.36^{\mathrm{a}}$ & 51 & $49.12 \pm 0.56^{\mathrm{a}}$ & 51 & $54.69 \pm 0.92^{\mathrm{a}}$ \\
\hline \multirow[t]{2}{*}{$\mathrm{BL}(\mathrm{cm})$} & Feb-March & 53 & $30.18 \pm 0.55^{\mathrm{a}}$ & 53 & $38.86 \pm 0.30^{\mathrm{a}}$ & 53 & $45.63 \pm 0.51^{\mathrm{a}}$ & 53 & $53.70 \pm 0.54^{\mathrm{a}}$ \\
\hline & April & 52 & $29.57 \pm 0.73^{\mathrm{a}}$ & 52 & $37.33 \pm 0.34^{\mathrm{a}}$ & 51 & $43.78 \pm 0.62^{\mathrm{a}}$ & 51 & $51.32 \pm 0.73^{\mathrm{a}}$ \\
\hline \multirow[t]{2}{*}{$\mathrm{CG}(\mathrm{cm})$} & Feb-March & 53 & $31.35 \pm 0.57^{\mathrm{a}}$ & 53 & $39.43 \pm 0.27^{\mathrm{a}}$ & 53 & $47.47 \pm 0.48^{\mathrm{a}}$ & 53 & $52.32 \pm 0.44^{\mathrm{a}}$ \\
\hline & April & 52 & $31.77 \pm 0.51^{\mathrm{a}}$ & 52 & $38.68 \pm 0.33^{\mathrm{a}}$ & 51 & $45.62 \pm 0.47^{\mathrm{a}}$ & 51 & $48.87 \pm 1.33^{\mathrm{a}}$ \\
\hline \multirow[t]{2}{*}{$\mathrm{HG}(\mathrm{cm})$} & Feb-March & 53 & $21.92 \pm 0.91^{\mathrm{a}}$ & 53 & $36.30 \pm 0.34^{\mathrm{a}}$ & 53 & $48.02 \pm 0.81^{\mathrm{a}}$ & 53 & $54.73 \pm 0.75^{\mathrm{a}}$ \\
\hline & April & 52 & $27.42 \pm 0.58^{\mathrm{a}}$ & 52 & $35.46 \pm 0.33^{\mathrm{a}}$ & 51 & $46.35 \pm 0.59^{\mathrm{a}}$ & 51 & $53.76 \pm 0.99^{\mathrm{a}}$ \\
\hline
\end{tabular}

BW: body weight, SH: shoulder height, HH: hip height, BL: body length, CG: chest girth, HG: hip girth

Different letters between row for a and $b$ were statistically significant difference $(\mathrm{P}<0.05)$ and for a and $\mathrm{c}$ were very significant difference $(\mathrm{P}<0.01)$ 
Table 4. Least square means (LSM) and standard error (SE) of body weight and body measurements from birth to 90 days old by year of kidding.

\begin{tabular}{|c|c|c|c|c|c|c|c|c|c|}
\hline \multirow[t]{2}{*}{ Traits } & \multirow[t]{2}{*}{ Year of kidding } & \multicolumn{2}{|c|}{ At Birth } & \multicolumn{2}{|c|}{30 days old } & \multicolumn{2}{|c|}{60 days old } & \multicolumn{2}{|c|}{90 days old } \\
\hline & & $\mathrm{N}$ & $\mathrm{LSM} \pm \mathrm{SE}$ & $\mathrm{N}$ & $\mathrm{LSM} \pm \mathrm{SE}$ & $\mathrm{N}$ & $\mathrm{LSM} \pm \mathrm{SE}$ & $\mathrm{N}$ & $\mathrm{LSM} \pm \mathrm{SE}$ \\
\hline \multirow[t]{2}{*}{ BW (kg) } & 2018 & 54 & $3.02 \pm 0.08^{\mathrm{a}}$ & 54 & $5.51 \pm 0.11^{\mathrm{a}}$ & 53 & $8.26 \pm 0.19^{\mathrm{a}}$ & 53 & $10.92 \pm 0.36^{\mathrm{b}}$ \\
\hline & 2019 & 51 & $2.94 \pm 0.07 \mathrm{~A}^{\mathrm{a}}$ & 51 & $4.34 \pm 0.09^{\mathrm{a}}$ & 51 & $5.88 \pm 0.15^{\mathrm{b}}$ & 51 & $7.95 \pm 0.23^{\mathrm{a}}$ \\
\hline \multirow[t]{2}{*}{$\mathrm{SH}(\mathrm{cm})$} & 2018 & 51 & $36.35 \pm 0.50^{\mathrm{a}}$ & 54 & $41.17 \pm 0.36^{\mathrm{a}}$ & 53 & $47.98 \pm 0.52^{\mathrm{a}}$ & 53 & $55.05 \pm 0.69^{\mathrm{a}}$ \\
\hline & 2019 & 54 & $34.14 \pm 0.57^{\mathrm{a}}$ & 51 & $40.87 \pm 0.34^{\mathrm{a}}$ & 51 & $47.38 \pm 0.52^{\mathrm{a}}$ & 51 & $52.12 \pm 0.40^{\mathrm{a}}$ \\
\hline \multirow[t]{2}{*}{$\mathrm{HH}(\mathrm{cm})$} & 2018 & 54 & $38.61 \pm 0.51^{\mathrm{a}}$ & 54 & $44.75 \pm 0.37^{\mathrm{a}}$ & 53 & $51.04 \pm 0.55^{\mathrm{a}}$ & 53 & $58.18 \pm 0.84^{\mathrm{b}}$ \\
\hline & 2019 & 51 & $32.94 \pm 0.67^{\mathrm{a}}$ & 51 & $40.96 \pm 0.33^{\mathrm{a}}$ & 51 & $49.45 \pm 0.55^{\mathrm{a}}$ & 51 & $52.88 \pm 0.38^{\mathrm{a}}$ \\
\hline \multirow[t]{2}{*}{$\mathrm{BL}(\mathrm{cm})$} & 2018 & 54 & $28.96 \pm 0.71^{\mathrm{a}}$ & 54 & $40.03 \pm 0.33^{\mathrm{a}}$ & 53 & $48.03 \pm 0.60^{\mathrm{a}}$ & 53 & $58.94 \pm 0.66^{\mathrm{b}}$ \\
\hline & 2019 & 51 & $30.80 \pm 0.56^{\mathrm{a}}$ & 51 & $36.16 \pm 0.29^{\mathrm{a}}$ & 51 & $41.38 \pm 0.50^{\mathrm{a}}$ & 51 & $49.08 \pm 0.44^{\mathrm{a}}$ \\
\hline \multirow[t]{2}{*}{$\mathrm{CG}(\mathrm{cm})$} & 2018 & 54 & $33.43 \pm 0.49^{\mathrm{a}}$ & 54 & $40.56 \pm 0.32^{\mathrm{a}}$ & 53 & $47.65 \pm 0.46^{\mathrm{a}}$ & 53 & $53.97 \pm 0.69^{b}$ \\
\hline & 2019 & 51 & $29.68 \pm 0.59^{\mathrm{a}}$ & 51 & $37.55 \pm 0.27^{\mathrm{a}}$ & 51 & $45.43 \pm 0.49 \mathrm{a}$ & 51 & $47.22 \pm 0.41^{\mathrm{a}}$ \\
\hline \multirow[t]{2}{*}{$\mathrm{HG}(\mathrm{cm})$} & 2018 & 54 & $28.32 \pm 0.58^{\mathrm{a}}$ & 54 & $36.95 \pm 0.33^{\mathrm{a}}$ & 53 & $44.62 \pm 0.59^{\mathrm{a}}$ & 53 & $52.89 \pm 0.99^{\mathrm{a}}$ \\
\hline & 2019 & 51 & $21.02 \pm 0.91^{\mathrm{a}}$ & 51 & $34.81 \pm 0.34^{\mathrm{a}}$ & 51 & $44.74 \pm 0.84^{\mathrm{a}}$ & 51 & $50.60 \pm 0.75^{\mathrm{a}}$ \\
\hline
\end{tabular}

Different letters between row for a and $b$ were statistically significant difference $(\mathrm{P}<0.05)$ and for a and $\mathrm{c}$ were very significant difference $(\mathrm{P}<0.01)$ 
Table 5. Heritability value $\left(\mathrm{h}^{2}\right)$ and standard error (SE) of body weight and body measurement from birth to 120 days old.

\begin{tabular}{lccccc}
\hline \hline Traits & At Birth & 30 days old & 60 days old & 90 days old & 120 days old \\
\hline Body weight & $0.59 \pm 0.12$ & $0.29 \pm 0.09$ & $0.11 \pm 0.04$ & $0.16 \pm 0.05$ & $0.15 \pm 0.10$ \\
Shoulder height & $0.10 \pm 0.08$ & $0.11 \pm 0.07$ & $0.13 \pm 0.05$ & $0.18 \pm 0.05$ & $0.16 \pm 0.10$ \\
Hip height & $0.04 \pm 0.07$ & $0.08 \pm 0.06$ & $0.03 \pm 0.07$ & $0,04 \pm 0.07$ & $0.05 \pm 0.08$ \\
Body length & $0.03 \pm 0.11$ & $0.05 \pm 0.07$ & $0.08 \pm 0.06$ & $0.15 \pm 0.06$ & $0.09 \pm 0.08$ \\
Chest girth & $0.15 \pm 0.09$ & $0.24 \pm 0.07$ & $0.16 \pm 0.06$ & $0.14 \pm 0.06$ & $0.09 \pm 0.12$ \\
Hip girth & $0.13 \pm 0.08$ & $0.34 \pm 0.10$ & $0.35 \pm 0.08$ & $0.28 \pm 0.09$ & $0.23 \pm 0.09$ \\
\hline
\end{tabular}

trait. There was also a correlation between total milk production and weaning weight $(\mathrm{rg}=0.37)$ and body sizes (body length, body height, and body girth) ( $\mathrm{rg}=$ 0.41-0.49) in Beethal goat in India. For lactation does, body height, hip height, and body length were with heritability values from low to moderate $\left(\mathrm{h}^{2}=0.10\right.$ 0.24). Contrarily, Kumar et al. (2016) found that heritability value of body measurements was high for body length, body height, and chest circumferences successively by $0.62 \pm 0.18,0.63 \pm 0.15,0.61 \pm 0.16$, and $0.63 \pm 0.18$

Rout et al. (2018) reported heritability value of body weight of Jamnapari goat, analyzed by animal model and sire model, tended decreased by the age of which higher heritability value of body weight was at birth $(0.14$ and 0.11$)$ and weaning $(0.160 .43)$, whilst lower heritability values were after weaning ages, i.e. at the ages: of 6 months $(0.19,0.37), 9$ months. $(0.12,0.11)$, and 12 months $(0.11,0.13)$. This showed a permanent environment factor during the pregnancy period of does had an important effect on the initial body weight. Similarly, Supakorn \& Pralomkarn (2012) stated that the initial body weight from birth to weaning age was not only determined by the genetic potency and its interaction with the environment but also significantly affected by the maternal effect. Based on these results the high heritability value of body weight at birth and weaning of the $G_{2}$ Sapera kid in this study might be quite large contributed by maternal permanent environment. Beside of that, low heritability value for certain age either in the specific body weight or most of the body size of $G_{2}$ Sapera kid probably because both the $G_{1}$ Sapera and G2 Sapera goat were in a very closed population and in the use of few male (2 Saanen bucks) to initially produce the $G_{1}$ Sapera goat at IRIAP.

\section{CONCLUSION}

The growth traits of $\mathrm{G}_{2}$ Sapera kids were affected by sex and year of kidding and slightly influenced by genetic (sires) factors. While heritability value $\left(\mathrm{h}^{2}\right)$ of both body weight and body measurement was low indicating a relatively narrow genetic difference of growth at the early age.

\section{REFERENCES}

Anggraeni A. 2014. Correction Factors of Lactation Length and Lactation Period on Milk Yield in Saanen Goat. In: Wiryawan K, Liang J, Devendra C, Takahashi J, Orskov E, Astuti D, Manalu W, Jayanegara A, Tjakradidjaja A, Suharti S, et al., editors. 2nd Asian-Australasian Dairy Goat Conf. Bogor (Indones): Bogor Agricultural University; p. 276.

Anggraeni A, Praharani L. 2017. Morphometric characteristics of Etawah Grade goat as a female population of crossed Sapera dairy goat at IRIAP. In: Wahyu Y, Wirnas D, Trikoesoemaningtyas, Ritonga AW, Marwiyah S, editors. PERIPI -2017 Int Semin. Bogor (Indones): PERIPI (Indonesian Breeding Science Society).

Anggraeni A, Praharani L, Saputra F, Sumantri C. 2020. Morphometrics of Etawah Grade goat females as dairy breeding stocks under intensive management system in Central Java. In: IOP Proc No 492. Univ. Hasanudin, Makassar. Indonesia.

Bharathidhasan A, Narayanan R, Gopu P, Subramanian A, Prabakaran R, Rajendran R. 2009. Effect of nongenetic factors on birth weight, weaning weight and preweaning gain of Barbari goat. Tamilnadu J Vet Anim Sci. 5:99103.

Caro-Petrovic V, Ilic Z, Ruzic-Muslic D, Petrovic MP, Petrovic MM, Tomic Z, Marinkov G. 2012. Analysis of environmental and genetic factors in growth characteristics of Balkan goat. Biotechnol Anim Husb. 28:275-282.

Devendra C. 2012. Dairy goats in Asia: Multifunctional relevance and contribution to food and nutrition security. In: Abdullah R, editor. Proc First Asia Dairy Goat Conf. Selangor (Malaysia): Institute Tropical Agriculture Publ.; p. 1-6.

Dudhe S, Yadav S, Nagda R, Pannu U, Gahlot G. 2015. Genetic and non-genetic factors affecting morphometry of Sirohi goats. Vet World. 8:1356-1363. 
Gholizadeh M, Rahimi Mianji G, Hashemi M, Hafezian H. 2010. Genetic parameter estimates for birth and weaning weights in Raeini goats. Czech $\mathrm{J}$ Anim Sci. 55:30-36.

Jafari S, Hashemi A. 2014. Estimation of genetic parameters for body measurements and their association with yearling liveweight in the Makuie sheep breed. S Afr J Anim Sci. 44:140.

Josiane M, Gilbert H, Johann D. 2020. Genetic Parameters for Growth and Kid Survival of Indigenous Goat under Smallholding System of Burundi. Animals. 10:135.

Kaunang D, Suyadi, Wahjuningsih S. 2013. Analisis litter size, berat lahir dan berat sapih hasil perkawinan kawin alami dan inseminasi buatan kambing Boer dan Peranakan Etawah (PE). J Ilmu-Ilmu Peternak. 23:4146.

Kugonza D, Stalder K, Rothschild M. 2014. Effects of buck and doe size on the growth performance and survival of their progeny. Livest Res Rural Dev. 26.

Kumar S, Dahiya SP, Malik ZS, Patil CS. 2016. Association of linear body measurements with growth traits in Harnali. Int. Res. J. Biological Sci. Vol. 5: 55-58.

Kuthu Z, Javed K, Awan K, Ahmad N, Ahad A. 2017. A Study on Phenotypic and Genetic Correlations between Birth Weight and other Growth Traits in Teddy Goat. J Dairy, Vet Anim Res. 5:187-190.

Mabrouk O, Sghaier N, Costa RG, Amor G, Amel AE, Delgado JV. 2010. The effect of non-genetic factors on the early body weights of Tunisian local goats. Rev Bras Zootec. 39:1112-1117.
Mioč B, Sušić V, Antunović Z, Prpić Z, Vnučec I, Kasap A. 2011. Study on birth weight and pre-weaning growth of Croatian multicolored goat kids. Vet Arh. 81:339-347.

Mohammed K, Kamal EL-den M, Dahmoush A. 2018. Heritability and variance components estimates for growth traits in Saudi Ardi goat and Damascus goat and their crosses. Asian Pacific J Reprod. 7:39-46.

Přibyl J, Krejčová H, Přibylova J, Misztal I, Tsuruta S, Mielenz N. 2008. Models for evaluation of growth of performance tested bulls. Czech J Anim Sci. 53:45-54.

Rout PK, Matika O, Kaushik R, Dige MS, Dass G, Singh MK, Bhusan S. 2018. Genetic analysis of growth parameters and survival potential of Jamunapari goats in semiarid tropics. Small Rumin Res. 165:124-130.

Sarma L, Nahardeka N, Goswami RN, Aziz A, Zaman G, Das A, Akhtar F. 2019. Non-genetic factors affecting preweaning growth and morphometric traits in Assam Hill goat. Vet World. 12:1327-1331.

Selvam R. 2018. Genetic and non-genetic factors affecting the birth weight of boer graded goats and non-descript goats. Int J Sci Environ Technol. 7:900-904.

Supakorn C, Pralomkarn W. 2012. Genetic parameter estimates for weaning weight and Kleiber ratio in goats. Songklanakarin. Songklanakarin J Sci Technol. 34:165172 .

Waheed A, Khan M. 2011. Genetic parameters of body measurements and their association with milk production in Beetal goats. Adv Agric Biotechnol. $1: 34-42$. 